5th International EEIGM/AMASE/FORGEMAT Conference on Advanced Materials Research IOP Publishing IOP Conf. Series: Materials Science and Engineering 5 (2009) 012016 doi:10.1088/1757-899X/5/1/012016

\title{
Preparation and firing of a TiC/Si powder mixture
}

\author{
I Kero ${ }^{1,3}$, M-L Antti ${ }^{1}$ and M Odén ${ }^{2}$ \\ ${ }^{1}$ Luleå University of Technology, Department of Applied Physics and Mechanical \\ Engineering, Division of Engineering Materials, 97187 Luleå, Sweden \\ ${ }^{2}$ Linköping University, Department of Physics, Division of Nanostructured Materials, \\ 58183 Linköping, Sweden
}

E-mail: ida.kero@ltu.se; Phone: +46 920492 269; Fax: +46 920491084

\begin{abstract}
This paper describes how the preparation and heat treatment of $\mathrm{TiC} / \mathrm{Si}$ powders influences the phase reactions during firing. The powders are prepared by milling and some effects of powder preparation are discussed. A solid state displacement reaction according to: $3 \mathrm{TiC}+2 \mathrm{Si} \rightarrow \mathrm{Ti}_{3} \mathrm{SiC}_{2}+\mathrm{SiC}$ is a priori expected to take place during heat treatment. The firing procedure is investigated with respect to the effect of heat treatment time and temperature on the phases produced, especially $\mathrm{Ti}_{3} \mathrm{SiC}_{2}$. Samples were heat treated in a graphite lined furnace. Heat treated samples are analysed by x-ray diffraction, scanning electron microscope and energy dispersive spectroscopy. $\mathrm{Ti}_{3} \mathrm{SiC}_{2}, \mathrm{TiC}$ and $\mathrm{SiC}$ are dominant in the final products. The highest amount of $\mathrm{Ti}_{3} \mathrm{SiC}_{2}$ is achieved for short holding times (2-4 hours) at high temperatures $\left(1350-1400^{\circ} \mathrm{C}\right) . \mathrm{Ti}_{3} \mathrm{SiC}_{2}$ appears to decompose at elevated temperatures or extended times, through a $\mathrm{Ti}_{3} \mathrm{SiC}_{2} \rightarrow \mathrm{TiC}+\mathrm{Si}(\mathrm{g})$ type reaction. The activation energy of $\mathrm{Ti}_{3} \mathrm{SiC}_{2}$ phase formation is determined to be $289 \mathrm{~kJ} / \mathrm{mol}$, using the Mehl-AvramiJohnson model.
\end{abstract}

\section{Introduction}

The ternary system Ti-Si-C has some interesting phases, for example a number of both binary and ternary intermetallics, see Figure 1. One of the most intriguing of these phases to materials scientists is the $\mathrm{Ti}_{3} \mathrm{SiC}_{2}$, which is a ceramic compound that exhibits a unique set of properties. It combines thermal and electrical conductivity and relative softness with chemical and thermal stability, elastic stiffness and excellent high-temperature mechanical properties.[1-3] It is resistant to thermal shock, damage tolerant and it can be machined by use of conventional high-speed tools without lubrication or cooling, which is of great technological importance for its potential applications.[1, 3] It is commonly referred to as a so called MAX phase; the MAX phases being a family of layered, ternary carbides and nitrides of general chemical formula $M_{n-1} A X_{n}$ where $M$ is an early transition metal, $A$ is an element from groups 12-16 in the periodic table of the elements, $\mathrm{X}$ is either carbon or nitrogen and $\mathrm{n}$ is an integer 13.

\footnotetext{
${ }^{3}$ Corresponding author
} 
5th International EEIGM/AMASE/FORGEMAT Conference on Advanced Materials Research IOP Publishing IOP Conf. Series: Materials Science and Engineering 5 (2009) 012016_doi:10.1088/1757-899X/5/1/012016

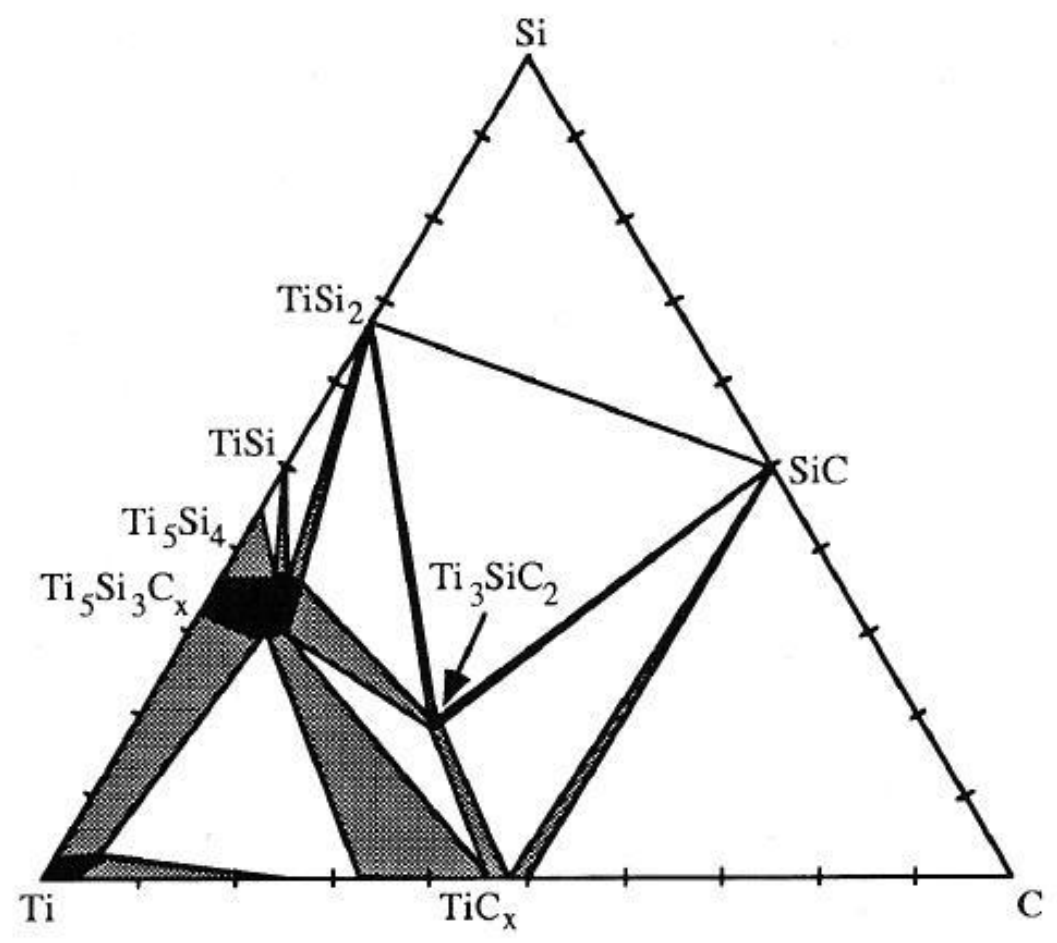

Figure 1. $1200^{\circ} \mathrm{C}$ isothermal section of the Ti-Si-C ternary phase equilibrium diagram by Arunajatesan \& Carim. [4]

Bulk samples of $\mathrm{Ti}_{3} \mathrm{SiC}_{2}$ have been produced by different approaches based on powder metallurgical techniques such as vacuum sintering,[5, 6] hot pressing,[7-10] hot isostatic pressing,[3, 11] self-propagation high-temperature synthesis,[12] mechanical alloying,[7, 13] and spark plasma sintering.[14] A range of powder mixtures have been used such as $\mathrm{TiH}_{2} / \mathrm{Si} / \mathrm{C}$,[7] $\mathrm{Ti} / \mathrm{SiC} / \mathrm{C}$,[8, 15] $\mathrm{Ti} / \mathrm{Si} / \mathrm{C}[4,16]$ or $\mathrm{Ti} / \mathrm{Si} / \mathrm{TiC} .[5,14]$ While some has attained single phase $\mathrm{Ti}_{3} \mathrm{SiC}_{2}$, [3, 17] many attempts have resulted in samples containing secondary phases such as $\mathrm{TiC}_{\mathrm{x}}, \mathrm{Ti}_{5} \mathrm{Si}_{3} \mathrm{C}_{\mathrm{x}}, \mathrm{Ti}_{5} \mathrm{Si}_{3}, \mathrm{TiSi}_{2}$ or unreacted raw materials in the final products.[18-20] The presence of other phases is not necessarily detrimental however; some studies have shown that by controlling the amount of the different phases in the samples it is possible to adjust the properties of the material. The binary carbides $\mathrm{TiC}$ and $\mathrm{SiC}$ have been shown to reinforce the $\mathrm{Ti}_{3} \mathrm{SiC}_{2}$, producing composites with improved properties and enhanced oxidation resistance [21]. Both $\mathrm{TiC}$ - and $\mathrm{SiC}-\mathrm{Ti}_{3} \mathrm{SiC}_{2}$ composites have been reported to possess damage tolerance, fracture toughness and thermal shock resistance comparable or even superior to monolithic $\mathrm{Ti}_{3} \mathrm{SiC}_{2}$ samples. [22-24]

Common in the synthesis of these materials is the use of starting powders containing pure titanium metal. Powdered $\mathrm{Ti}$ is highly reactive and must be handled with great care to safety measures [25] which is a disadvantage in terms of an up scaled production. If comparable material could be synthesised from cheaper and less hazardous starting powders it would be a great advantage for industrialised production.

There is consensus in the literature, with some minor variations, on the route of formation of $\mathrm{Ti}_{3} \mathrm{SiC}_{2}$ from powder mixtures including $\mathrm{Ti}$ metal, regardless of the sintering method of choice. This reaction pathway includes $\mathrm{Ti}_{5} \mathrm{Si}_{3} \mathrm{C}_{\mathrm{x}}$ as a necessary intermediate step for the formation of $\mathrm{Ti}_{3} \mathrm{SiC}_{2}$. [6, 26] This reaction pathway is not, however, applicable to TiC/Si powders since $\mathrm{Ti}_{5} \mathrm{Si}_{3} \mathrm{C}_{\mathrm{x}}$ has not been observed. Yet, $\mathrm{Ti}_{3} \mathrm{SiC}_{2}$ has been reported to form in spite of the relatively low reactivity of TiC. [27]

In this paper we report on the sintering process of a TiC/Si powder mixture. The a priori expected reaction is: 
5th International EEIGM/AMASE/FORGEMAT Conference on Advanced Materials Research IOP Publishing IOP Conf. Series: Materials Science and Engineering 5 (2009) 012016 doi:10.1088/1757-899X/5/1/012016

$$
3 \mathrm{TiC}+2 \mathrm{Si} \rightarrow \mathrm{Ti}_{3} \mathrm{SiC}_{2}+\mathrm{SiC}
$$

The phase reactions are investigated with respect to the effect of sintering time and temperature on the phases produced, especially $\mathrm{Ti}_{3} \mathrm{SiC}_{2}$.

\section{Experimental}

The powders used were $\mathrm{TiC}$ (Aldrich) and $\mathrm{Si}$ (Merck) and they were mixed with a molar ratio of 3:2, corresponding to the stoichiometry of the expected reaction in equation (1). One sample, here denoted P1, was ball milled (Siemens: Elektra Tailfingen T10) during 96 hours. Another powder, here denoted P2, was first ball milled for 96 hours and then transferred to an attritor (Walther Flender: 4AP) and attrition milled for 24 hours. Finally, a third powder, here denoted P3, was ball milled for $24 \mathrm{~h}$.

The as-milled powders were evaluated using a scanning electron microscope (SEM, JEOL: JSM 6460LV), and by measuring the Brunaur-Emmett-Teller (BET) surface area (Micromeritics: ASAP 2000). The compaction of the green body was performed by the combination of two methods operating at room temperature: cold uniaxial pressing (MFL Systeme Prüf und Mess: UPD6) and cold isostatic pressing (Autoclave Engineers: STD). The compaction was performed under pressures of 10 $\mathrm{MPa}$ and $300 \mathrm{MPa}$ respectively. The furnace experiments took place in a reaction sintering furnace with graphite heating elements (Conrad Engelko Technik) in which the samples were embedded in boron nitride. Furnace heat treatments were performed at different temperatures and with varying holding times, under a vacuum of approximately 0.02 mbar. Powder samples were sintered at varying temperatures and holding times. The parameters of the sintering experiments are summarised in Table 1. The as-sintered microstructure was evaluated with x-ray diffraction (XRD, Philips: MRD), using $\mathrm{CuK}_{\alpha}$ radiation and a proportional detector and by SEM with energy dispersive spectroscopy (EDS).

The activation energy of $\mathrm{Ti}_{3} \mathrm{SiC}_{2}$ formation was calculated using the Arrhenius equation and MehlAvrami-Johnson (MAJ) theory. [15] The kinetics of $\mathrm{Ti}_{3} \mathrm{SiC}_{2}$ formation was modelled using the MAJ equation (2) and the activation energy of the process was calculated using the Arrhenius equation (3).

The MAJ equation: $f(t)=1-\exp (K t)^{n}$

Where $\mathrm{n}$ is the Avrami exponent and $\mathrm{K}$ is the reaction rate constant.

The Arrhenius equation: $K(T)=K_{0} \exp \left(\frac{-E}{k T}\right)$

Where $\mathrm{K}$ is the frequency factor, $\mathrm{E}$ is the activation energy, $\mathrm{k}$ is the Bolzmann constant and $\mathrm{T}$ is the temperature.

Table 1. Summary of the reaction furnace experiments.

\begin{tabular}{|l|l|l|l|}
\hline Sample & Milling method & Temp. $\left({ }^{\circ} \mathrm{C}\right)$ & Time $(\mathrm{h})$ \\
\hline P1 & Ball mill 96h & 1200,1250 & 4 \\
\hline P1 & Ball mill 96h & 1300 & $\begin{array}{l}1,2,3,4,5,6,8, \\
10,12\end{array}$ \\
\hline P1 & Ball mill 96h & 1350,1400 & $1,2,4$ \\
\hline P1 & Ball mill 96h & 1500 & 8,24 \\
\hline P2 & $\begin{array}{c}\text { Ball mill 96h }+ \\
\text { Attritor 24h }\end{array}$ & 1500 & 8,24 \\
\hline P3 & Ball mill 24h & 1250 & 2.5 \\
\hline
\end{tabular}


5th International EEIGM/AMASE/FORGEMAT Conference on Advanced Materials Research IOP Publishing IOP Conf. Series: Materials Science and Engineering 5 (2009) $012016 \quad$ doi:10.1088/1757-899X/5/1/012016

\section{Results and Discussion}

The ball milled P1 had a BET surface area of $3,63 \mathrm{~m}^{2} / \mathrm{g}$ and the ball- and attrition milled P2 had a BET surface area of $11,25 \mathrm{~m}^{2} / \mathrm{g}$. P1 was significantly coarser than P2 and had a wider particle size distribution, see Figure 2. SEM images of the as-milled powders are displayed in Figure 2a) and c). The majority of the P1 particles were of sizes between 1 and $5 \mu \mathrm{m}$ but also particles smaller than 0.5 $\mu \mathrm{m}$ and large particles up to $15 \mu \mathrm{m}$ were observed. The P2 displayed a narrower particle size distribution and small particles, mainly ranging from 0.1 to $1 \mu \mathrm{m}$. SEM images of the as-sintered products after heat treatment in $1500^{\circ} \mathrm{C}$ for $24 \mathrm{~h}$ are displayed in Figure $2 \mathrm{~b}$ ) \& d). Both samples have a porous microstructure. The $\mathrm{P} 1$ sample has finer particles with more rounded shapes than the $\mathrm{P} 2$. The $\mathrm{P} 3$ powder turned out to be very similar to the $\mathrm{P} 1$.

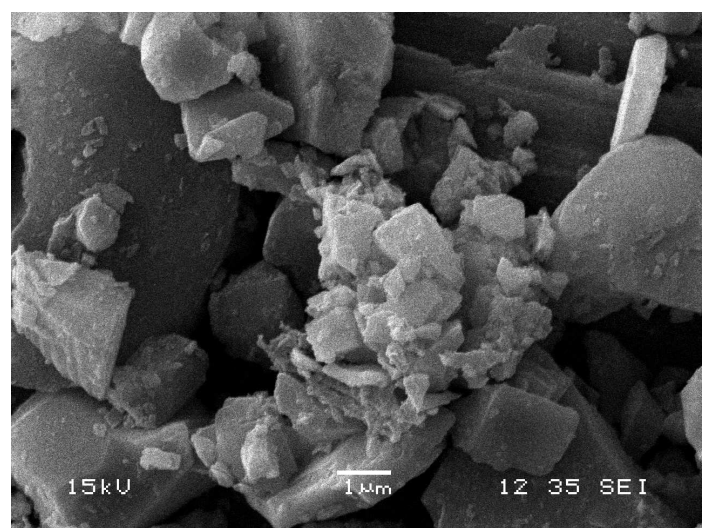

Figure $2 \mathrm{a}$

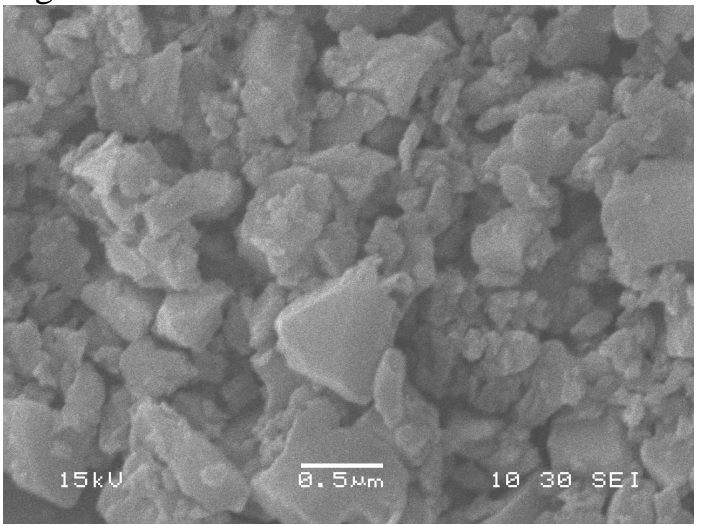

Figure 2c
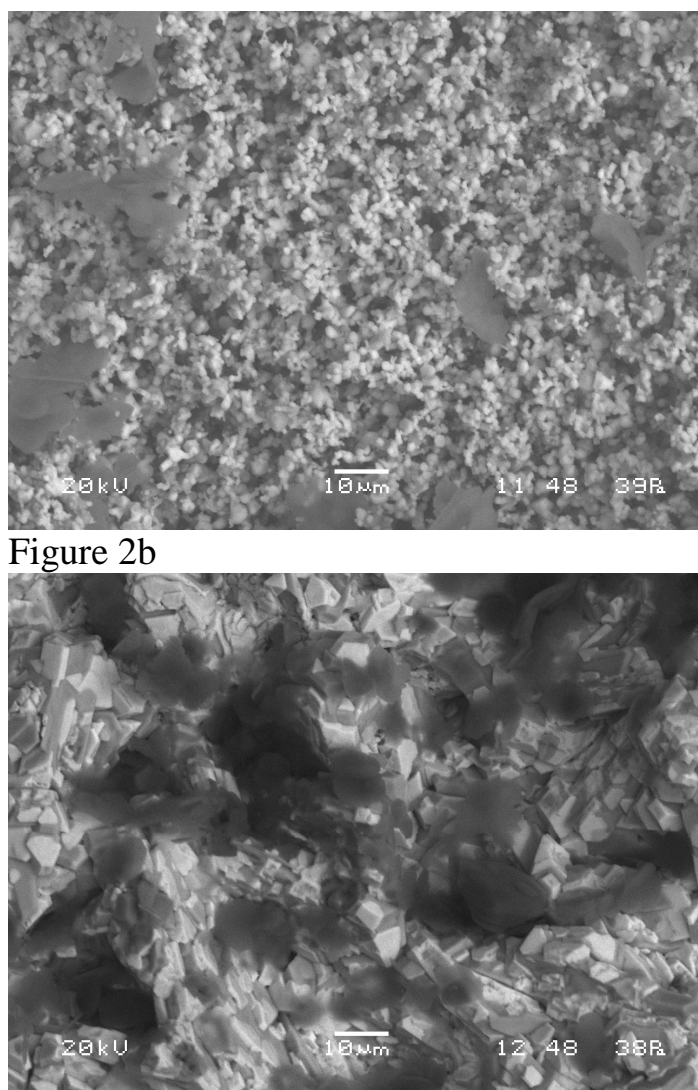

Figure $2 d$

Figure 2. SEM images of the raw powders and of products sintered in the graphite furnace at $1500^{\circ} \mathrm{C}$ for $24 \mathrm{~h}$. a): P1 raw powder; b): P1 sintered product; c): P2 raw powder; d): P2 sintered product..

After heat treatment in vacuum in the reaction sintering furnace, at $1500^{\circ} \mathrm{C}$ for 8 and 24 hours, the P1 samples contained $\mathrm{TiC}$ and $\mathrm{Ti}_{3} \mathrm{SiC}_{2}$ as the main phases with minor amounts of $\mathrm{SiC}$, see Figure 3 . The 8 hour sintering run rendered somewhat more $\mathrm{Ti}_{3} \mathrm{SiC}_{2}$ than the 24 hour run. The $\mathrm{P} 2$ samples sintered under the same conditions also contained $\mathrm{TiC}$ but there were no $\mathrm{Ti}_{3} \mathrm{SiC}_{2}$ or $\mathrm{SiC}$ present. The absence of $\mathrm{Ti}_{3} \mathrm{SiC}_{2}$ in the $\mathrm{P} 2$ samples is likely a consequence of reaction kinetics. As $\mathrm{Ti}_{3} \mathrm{SiC}_{2}$ has a tendency to decompose, it is likely to have formed and decomposed in the $\mathrm{P} 2$ samples at an earlier stage than in the P1. The particle size of the P2 powder was smaller than the P1, due to attrition milling and since a more finely divided powder exhibits shorter diffusion paths, the rate of reaction is higher. This kinetic effect has also been confirmed by thermal analysis, results of which will be 
5th International EEIGM/AMASE/FORGEMAT Conference on Advanced Materials Research IOP Publishing IOP Conf. Series: Materials Science and Engineering 5 (2009) $012016 \quad$ doi:10.1088/1757-899X/5/1/012016

published elsewhere. An unknown phase was detected; it is likely a decomposition product and possibly a non-stoichiometric adaptation of the $\mathrm{Ti}_{3} \mathrm{SiC}_{2}$ phase.

The extra hours of attrition milling of the $\mathrm{P} 2$ powder produced no advantage in terms of the production of phases of interest, such as silicides or ternary or binary carbides. Therefore, the ball milled P1 powder was chosen for further furnace experiments.

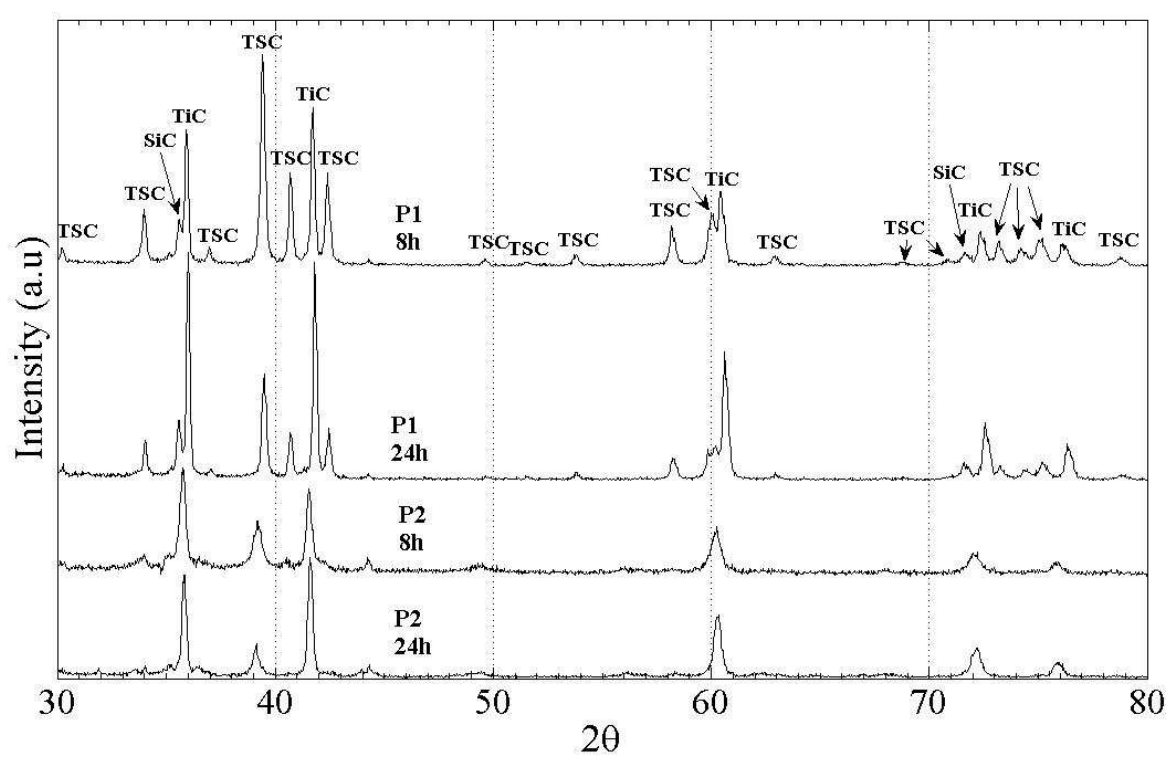

Figure 3. X-ray diffractograms of the $\mathrm{P} 1$ and $\mathrm{P} 2$ samples after sintering at $1500{ }^{\circ} \mathrm{C}$ for 8 and 24 hours respectively. $\mathrm{Ti}_{3} \mathrm{SiC}_{2}$ peaks are denoted TSC in the figure.

Figure 4 shows X-ray diffractograms of P1 samples sintered at different temperatures and the phase composition is summarised in Table 2 . These samples were sintered for 4 hours at $1200-1400^{\circ} \mathrm{C}$, the diffractograms in Figure 4 show that the main phases are $\mathrm{Ti}_{3} \mathrm{SiC}_{2}, \mathrm{TiC}$ and $\mathrm{SiC}$ with $\mathrm{TiSi}_{2}$ present in samples sintered at the lower temperatures. More $\mathrm{Ti}_{3} \mathrm{SiC}_{2}$ was found in these samples compared to those sintered at $1500^{\circ} \mathrm{C}$. These results are in agreement with those of $\mathrm{Li}$ et al.[19] and Córdoba et al.[18] who observed secondary phases $\mathrm{SiC}$ and $\mathrm{TiC}$ in their final products, prepared from $\mathrm{TiC} / \mathrm{Si}$ powders by hot pressing and pressureless sintering in argon.

Samples sintered at 1200 and $1250^{\circ} \mathrm{C}$ produced significantly less $\mathrm{Ti}_{3} \mathrm{SiC}_{2}$ and $\mathrm{SiC}$ than samples sintered at $1300-1400^{\circ} \mathrm{C}$. Titanium disilicide, $\mathrm{TiSi}_{2}$ is present only at the lower temperatures and appears to be an intermediate phase to the $\mathrm{Ti}_{3} \mathrm{SiC}_{2}$ formation.

Although the presence of $\mathrm{Ti}_{5} \mathrm{Si}_{3} \mathrm{C}_{\mathrm{x}}$ cannot be completely ruled out, as its two main diffraction peaks overlap those of the $\mathrm{Ti}_{3} \mathrm{SiC}_{2}$, no significant amount was detected in this study. This contradicts the hypothesis based on thermodynamical calculations presented by $\mathrm{Li}$ et al.[19] stating that $\mathrm{Ti}_{5} \mathrm{Si}_{3} \mathrm{C}_{\mathrm{x}}$ should be the main intermediate phase for the development of a $\mathrm{Ti}_{3} \mathrm{SiC}_{2}$ structure. 
5th International EEIGM/AMASE/FORGEMAT Conference on Advanced Materials Research IOP Publishing IOP Conf. Series: Materials Science and Engineering 5 (2009) 012016 doi:10.1088/1757-899X/5/1/012016

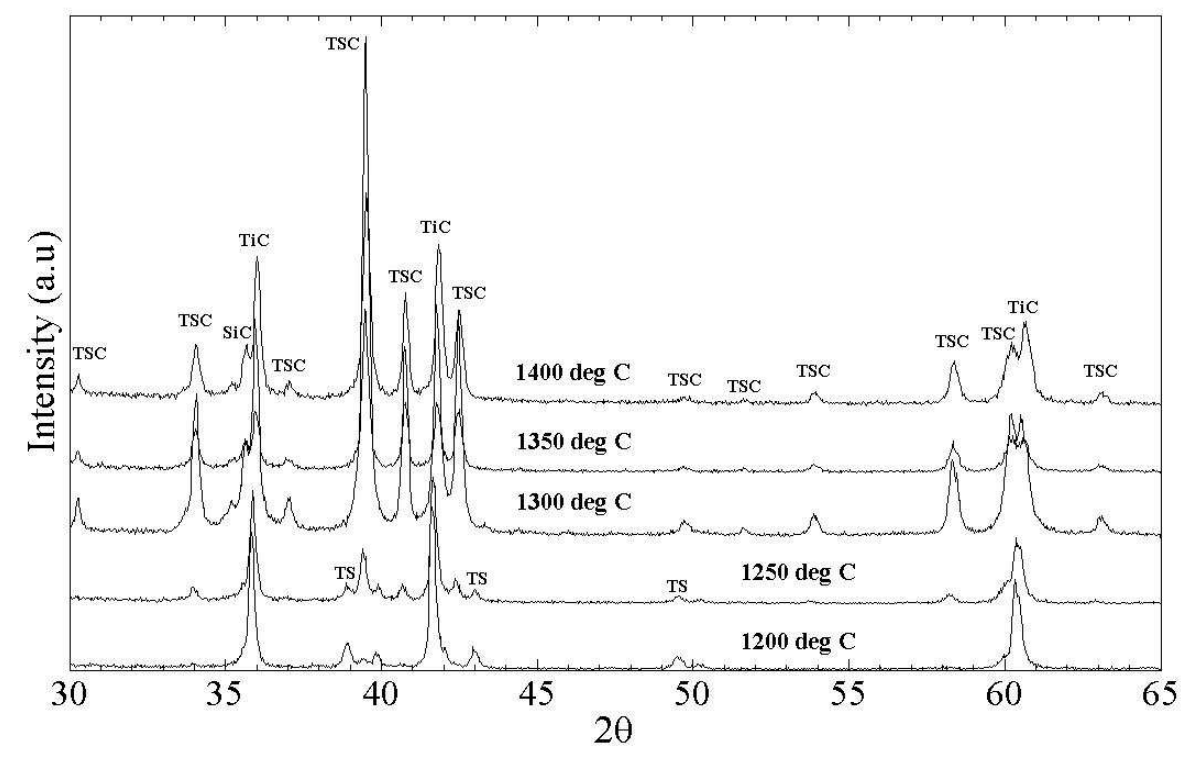

Figure 4. X-ray diffractograms of P1 samples sintered during $4 \mathrm{~h}$ at different temperatures. $\mathrm{TiSi}_{2}$ and $\mathrm{Ti}_{3} \mathrm{SiC}_{2}$ peaks are denoted $\mathrm{TS}$ and TSC respectively.

Table 2. Phase composition of P1 samples sintered for 4 hours.

\begin{tabular}{|l|l}
\hline Temperature $\left({ }^{\circ} \mathrm{C}\right)$ & Phases present \\
\hline 1200 & $\mathrm{TiC}, \mathrm{TiSi}_{2},($ traces of $\mathrm{SiC})$ \\
\hline 1250 & $\mathrm{TiC}, \mathrm{TiSi}_{2}, \mathrm{SiC}_{\mathrm{Ti}} \mathrm{SiC}_{2}$ \\
\hline $1300-1400$ & $\mathrm{TiC}, \mathrm{SiC}, \mathrm{Ti}_{3} \mathrm{SiC}_{2}$ \\
\hline
\end{tabular}

The influence of sintering time is displayed in Figure 5, it shows x-ray diffractograms of P1 samples sintered at $1300^{\circ} \mathrm{C}$ and held for different times. $\mathrm{Ti}_{3} \mathrm{SiC}_{2}, \mathrm{TiC}$ and $\mathrm{SiC}$ were the main phases and small amounts of $\mathrm{TiSi}_{2}$ were traceable in samples held at temperature for $4 \mathrm{~h}$ or less. Most $\mathrm{Ti}_{3} \mathrm{SiC}_{2}$ was attained when the sample was held at temperature for 3 hours. Generally, short holding times (2-4 hours) produced more $\mathrm{Ti}_{3} \mathrm{SiC}_{2}$ than longer, suggesting a breakdown of $\mathrm{Ti}_{3} \mathrm{SiC}_{2}$ over time. The $\mathrm{SiC}$ content appears to change very little with changes in holding time.

From these sintering experiments, it is clear that sintering time and temperature have a stronger effect on the formation of $\mathrm{Ti}_{3} \mathrm{SiC}_{2}$ and $\mathrm{TiSi}_{2}$; whereas the binary carbides $\mathrm{TiC}$ and $\mathrm{SiC}$ are less reactive and therefore less dependent on time and temperature. In order to achieve large amounts of $\mathrm{Ti}_{3} \mathrm{SiC}_{2}$ the sintering time should be shifted towards shorter holding times as the sintering temperature is increased. In this study, most $\mathrm{Ti}_{3} \mathrm{SiC}_{2}$ was achieved when sintering at $1400^{\circ} \mathrm{C}$ with a hold for 1 hour. Most $\mathrm{TiSi}_{2}$ was produced when sintering at $1200^{\circ} \mathrm{C}$ with a hold for 4 hours. The evolutions of the TiC and $\mathrm{Ti}_{3} \mathrm{SiC}_{2}$ phases are strongly interconnected; the amount of $\mathrm{TiC}$ decreases while the amount of $\mathrm{Ti}_{3} \mathrm{SiC}_{2}$ increases, but when the $\mathrm{Ti}_{3} \mathrm{SiC}_{2}$ amount is reduced during the decomposition reaction, the TiC content is raised again. These results confirm $\mathrm{Ti}_{3} \mathrm{SiC}_{2}$ decomposition into $\mathrm{TiC}$ and $\mathrm{Si}$ as proposed by Racault et al.[28] 
5th International EEIGM/AMASE/FORGEMAT Conference on Advanced Materials Research IOP Publishing IOP Conf. Series: Materials Science and Engineering 5 (2009) 012016 doi:10.1088/1757-899X/5/1/012016

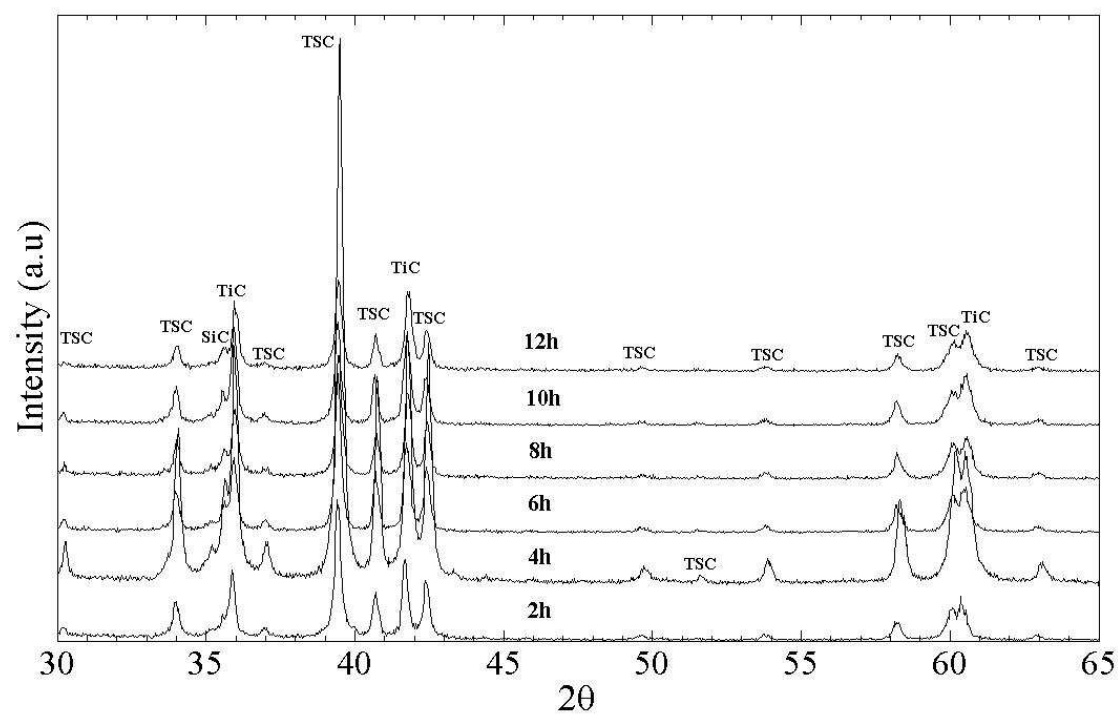

Figure 5. X-ray diffractograms of $\mathrm{P} 1$ samples sintered at $1300^{\circ} \mathrm{C}$ for different times. $\mathrm{Ti}_{3} \mathrm{SiC}_{2}$ peaks are denoted TSC in the Figure.

Figure 6a) shows an SEM image of a $\mathrm{P} 3$ sample sintered at $1250^{\circ} \mathrm{C}$ for $2,5 \mathrm{~h}$. Figures $6 \mathrm{~b}$ ), c) and d) shows the EDX mappings of the same area. The samples were not perfectly homogeneous and the Figure shows an inhomogeneous area. EDS analysis of the area revealed different chemical compositions within different, well defined parts of the sample. This will naturally influence the phase composition of the samples. Areas rich in $\mathrm{Si}$ also tend to be poor in $\mathrm{Ti}$ and vice versa. This indicates that $\mathrm{SiC}$ and $\mathrm{TiSi}_{2}$ are dominating in some, well defined areas rich in $\mathrm{Si}$. Therefore, it requires a certain temperature and/or holding time $\left(1300^{\circ} \mathrm{C}, 4 \mathrm{~h}\right)$ to allow the diffusion of silicon to more Ti rich areas, which appears to be necessary for $\mathrm{Ti}_{3} \mathrm{SiC}_{2}$ to form in any significant amounts. The carbon distribution is relatively uniform, partly because of the low atomic number of carbon. From the phase diagram in Figure 1 however, it is also clear that the carbon content should not vary greatly with varying phase composition.

Further investigation showed that the powder inhomogeneity originates from segregation, caused by a degree of particle sedimentation in the drying step during powder preparation. This effect was found to be reduced by extensive mechanical stirring throughout the entire milling and subsequent drying processes.

The activation energy was found to be $289 \mathrm{~kJ} / \mathrm{mol}$, which is in good agreement with the value 380 $\mathrm{kJ} / \mathrm{mol}$ reported by Wu et al.[15] for the $\mathrm{Ti}_{3} \mathrm{SiC}_{2}$ formation from $\mathrm{Ti} / \mathrm{SiC} / \mathrm{C}$ powders with intermediate phases $\mathrm{TiC}_{\mathrm{x}}, \mathrm{Ti}_{5} \mathrm{Si}_{3} \mathrm{C}_{\mathrm{x}}$ and free carbon. 
5th International EEIGM/AMASE/FORGEMAT Conference on Advanced Materials Research IOP Publishing IOP Conf. Series: Materials Science and Engineering 5 (2009) 012016_doi:10.1088/1757-899X/5/1/012016

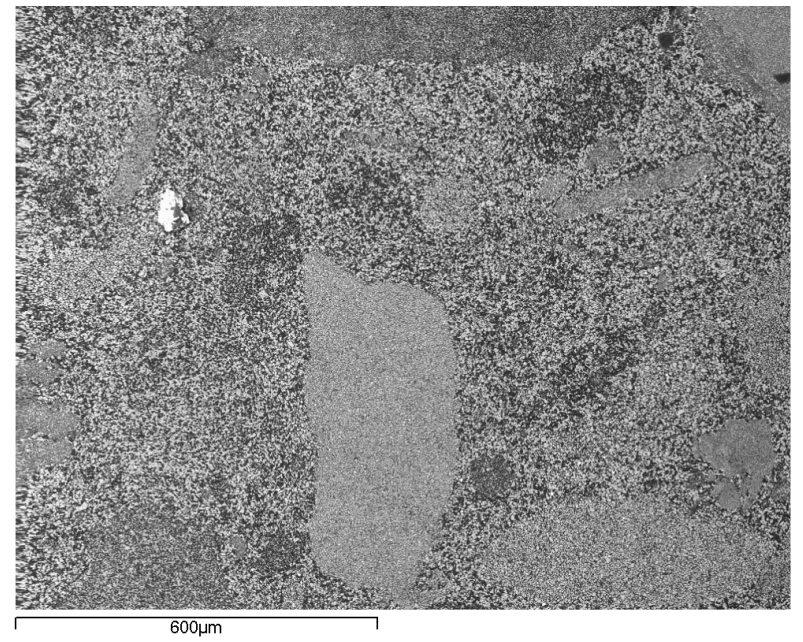

Figure 6a

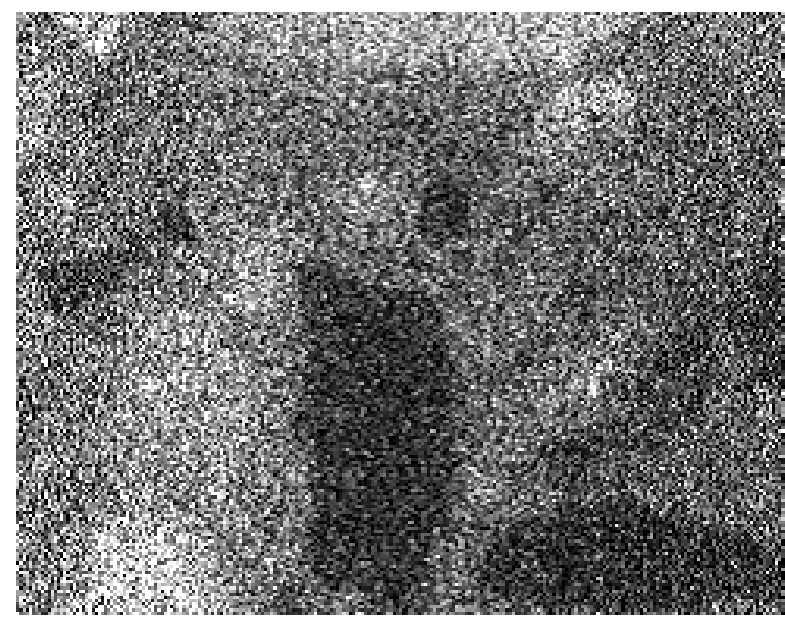

600urn

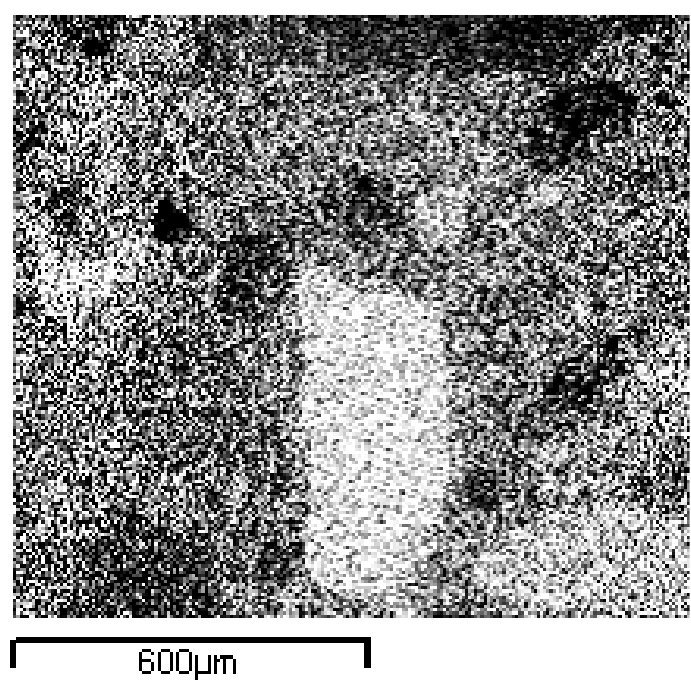

Figure $6 b$

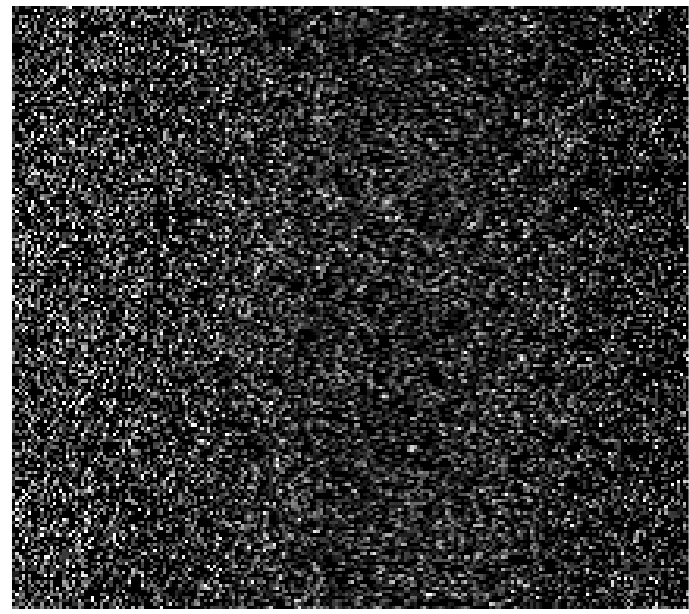

600urn

Figure $6 \mathrm{c}$

Figure 6d

Figure 6. SEM micrographs of $\mathrm{P} 3$ sintered at $1250^{\circ} \mathrm{C}$ for $2,5 \mathrm{~h}$; a) backscattered electron mode; b) EDS mapping of titanium showing light areas rich in Ti and dark areas poor in Ti; c) EDS mapping of silicon showing light areas rich in $\mathrm{Si}$ and dark areas poor in $\mathrm{Si}$; d) EDS mapping of carbon showing a relatively uniform distribution of $\mathrm{C}$. 
5th International EEIGM/AMASE/FORGEMAT Conference on Advanced Materials Research IOP Publishing IOP Conf. Series: Materials Science and Engineering 5 (2009) 012016_doi:10.1088/1757-899X/5/1/012016

\section{Conclusions}

It is possible to synthesise $\mathrm{Ti}_{3} \mathrm{SiC}_{2}$ phase by ceramic powder processing from a starting powder of $3 \mathrm{TiC} / 2 \mathrm{Si}$, i.e. without the expensive and highly reactive Ti. The activation energy for the formation of $\mathrm{Ti}_{3} \mathrm{SiC}_{2}$ was found to be $289 \mathrm{~kJ} / \mathrm{mol}$ from $\mathrm{TiC} / \mathrm{Si}$ starting powders.

$\mathrm{SiC}$ and $\mathrm{TiC}$ were present in all furnace heated samples. TiC is present both as a reactant involved in the formation of the $\mathrm{Ti}_{3} \mathrm{SiC}_{2}$ and as a product of its decomposition.

No $\mathrm{Ti}_{5} \mathrm{Si}_{3} \mathrm{C}_{\mathrm{x}}$ was observed in this study, and it is unlikely to be a key feature to the formation of $\mathrm{Ti}_{3} \mathrm{SiC}_{2}$ from $\mathrm{TiC} / \mathrm{Si}$ powders.

$\mathrm{TiSi}_{2}$ is suggested to be an intermediate phase in the process of $\mathrm{Ti}_{3} \mathrm{SiC}_{2}$ formation from $\mathrm{TiC} / \mathrm{Si}$ starting powders.

The $\mathrm{Ti}_{3} \mathrm{SiC}_{2}$ and the $\mathrm{TiSi}_{2}$ are very sensitive to holding times and temperatures, decomposing if either is extensive. Short holding times at temperatures of $1300-1400^{\circ} \mathrm{C}$ are advantageous for the development of $\mathrm{Ti}_{3} \mathrm{SiC}_{2}$, whereas temperatures must be limited to $1250^{\circ} \mathrm{C}$ for $\mathrm{TiSi}_{2}$. $\mathrm{Ti}_{3} \mathrm{SiC}_{2}$ decomposed into $\mathrm{TiC}$ and other decomposition products such as gaseous silicon.

The particle size influences the rates of reactions in the sintered samples. An uneven size distribution of the particles of the starting powder is not necessarily detrimental for the formation of $\mathrm{Ti}_{3} \mathrm{SiC}_{2}$ during sintering.

The homogeneity of the powders influences the time and temperature of the heat treatments required for substantial formation of $\mathrm{Ti}_{3} \mathrm{SiC}_{2}$.

\section{Acknowledgement}

The authors gratefully acknowledge the financial support from the Swedish National Graduate School of Space Technology and the Swedish Research Council.

\section{References}

[1] Barsoum M W (2000) Prog. Solid St. Chem. 28 201-81.

[2] Barsoum M W, El-Raghy T, Rawn C J et al. (1999) Journal of Physics and Chemistry of Solids 60 429-39.

[3] Barsoum M Wand El-Raghy T (2001).

[4] Arunajatesan Sand Carim A H (1995) Journal of the American Ceramic Society 78 66772.

[5] Sun Z M, Yang Sand Hashimoto H (2004) Ceramics International 30 1873-77.

[6] Istomin P V, Nadutkin A V, Ryabkov I et al. (2006) Inorganic Materials 42 250-5.

[7] Ramachandran V S, Paroli R M, Beaudoin J J et al. (2002) Handbook of Thermal Analysis of Construction Materials, (Noyes Publications: William Andrew Pub., Norwich, N.Y.2002).

[8] Barsoum M Wand El-Raghy T (1996) J. Am. Ceram. Soc. 79 1953-56.

[9] Zhou Y, Sun Z, Chen S et al. (1998) Mat. Res. Innovat. 2 142-6.

[10] Yong Ming L, Wei P, Li S et al. (2002) Ceramics International 28 227-30.

[11] Gao N F, Miyamoto Yand Zhang D (2002) Materials Letters 55 61-6.

[12] Riley D P, Kisi E H, Hansen T C et al. (2002) J.Am.Ceram.Soc. 85 2417-24.

[13] Orthner H R, Tomasi Rand Botta F. W J (2002) Materials Science and Engineering A336 202-8.

[14] Gao N F, Li J T, Zhang D et al. (2002) Journal of the European Ceramic Society 22 2365-70.

[15] Wu E, Riley D P, Kisi E H et al. (2005) Journal of the European Ceramic Society 25 3503-08.

[16] Li S B, Zhai H X, Zhou Y et al. (2005) Materials Science and Engineering A $407315-$ 21. 
5th International EEIGM/AMASE/FORGEMAT Conference on Advanced Materials Research IOP Publishing IOP Conf. Series: Materials Science and Engineering 5 (2009) $012016 \quad$ doi:10.1088/1757-899X/5/1/012016

[17] Lifshin E (1999) X-ray characterization of materials, (Wiley-VCH, cop. 1999, Weinheim).

[18] Córdoba J M, Sayagués M J, Alcalá M D et al. (2007) J. Am. Ceram. Soc. 90 825-30.

[19] Li S-B, Xie J-X, Zhang L-T et al. (2004) Materials Science and Engineering A 381 51-6.

[20] Radhakrishnan R, Williams J Jand Akinc M (1999) Journal of Alloys and Compounds 285 85-8.

[21] Li S, Xie J, Zhang L et al. (2003) Materials Letters 3048-56.

[22] Ho-Duc L H, El-Raghy Tand Barsoum M W (2003) Journal of Alloys and Compounds 303-12.

[23] Zhang J, Wang L, Jiang W et al. (2008) Materials Science and Engineering 137-43.

[24] Zhang J, Wu T, Wang L et al. (2008) Composites Science and Technology 499-505.

[25] Poulsen E (2000) JOM: The Member Journal of TMS 50 13-7.

[26] Wu E, Kisi E H, Riley D P et al. (2002) Journal of the American Ceramic Society 85 3084-86.

[27] Radhakrishnan R, Henager J, C. H., Brimhall J L et al. (1996) Scripta Materialia 34 1809-14.

[28] Racault C, Langlais Fand Naslain R (1994) Journal of Materials Science 29 3384-92. 